\title{
Communication
}

[Comunicação]

\section{Use of human intravaginal tampon embedded with natural progesterone induces synchronous estrus in Santa Inês ewes}

\author{
[Uso de tampão intravaginal humano embebido com progesterona humana para indução e \\ sincronização de estro em ovelhas Santa Inês] \\ J.F. Prates ${ }^{1}$, V.L. Brair ${ }^{2}$, A.L.R.S. Maia ${ }^{2,}$ J.M.G.Souza- Fabjan ${ }^{2}$, F.Z. Brandão ${ }^{2}$, \\ G.C. Bonato ${ }^{3}$, J.F. Fonseca ${ }^{4 *}$ \\ ${ }^{1}$ Instituto Federal de Educação, Ciência e Tecnologia do Sudeste de Minas Gerais - Rio Pomba, MG \\ ${ }^{2}$ Universidade Federal Fluminense - Niterói, RJ \\ ${ }^{3}$ Universidade Federal de Viçosa - Viçosa, MG \\ ${ }^{4}$ Embrapa Caprinos e Ovinos - Coronel Pacheco, MG
}

The production of Santa Inês sheep in Brazil is very important to farmers because they are rustic, adapted to most part of gastrointestinal parasites and have good maternal ability (Sousa et al., 2003; Amarante et al., 2004). To maintain these characteristics, the animals are selected, and reproductive biotechnologies are applied to induce estrus with progestagens throughout the year, due to their seasonality. Different strategies of estrus induction and synchronization are used worldwide (Balaro et al., 2017) but, traditionally, intravaginal progestagen devices are often applied. One of the disadvantages of hormonal treatment is the cost itself. Currently, there are three different commercial brands in Brazil and overall, the cost of those devices is relatively high. Alternatives must be proposed in order to make efficient treatments, without adversely affecting the reproductive efficiency. Therefore, the aim of this study was to evaluate the efficiency of three protocols of synchronous estrus induction during the transition period in Santa Inês ewes.

This study was approved by Embrapa Dairy Cattle Animal Care Committee (2512100516) and it was conducted under the principles of Brazilian Society of Laboratory Animal Science. The experiment was carried out on February, during the transition season in Coronel Pacheco $\left(21^{\circ} 35^{\prime} \mathrm{S}\right.$ and $\left.43^{\circ} 15^{\prime} \mathrm{W}\right)$, Minas Gerais, Brazil.
All ewes were kept in an intensive system and fed with corn silage, chopped Pennisetum purpureum, Cynodon spp. hay. Furthermore, a balanced concentrate supplement was given according to their demand, as well as mineralized salt (Caprinofós ${ }^{\circledR}$ Tortuga, São Paulo, Brazil) and drinking water were available ad libitum.

A total of 24 pluriparous ewes was used. Ewes were equally allocated into three treatments according to their parity, body weight (BW) and body condition score (BCS, range 1 to 5 ): CONTROL, OB 200 and OB 400. Ewes in the CONTROL group $(\mathrm{n}=8 ; 57.6 \pm 12.0 \mathrm{~kg}, \mathrm{BCS}$ $3.3 \pm 0.8$ ) received a progesterone releasing device containing $330 \mathrm{~g}$ progesterone $\left(\mathrm{CIDR}^{\circledR}\right.$, Pfizer Animal Health, São Paulo, Brazil). Ewes in the other two groups received intravaginal Mini tampon (o.b. ${ }^{\circledR}$, Johnson \& Johnson, São José dos Campos, Brazil) embedded with 200mg natural human progesterone (Evocanil $^{\circledR}$; Zodiac Produtos Farmacêuticos S/A, Pindamonhangaba, Brazil) (OB 200, $\mathrm{n}=8 ; 58.5 \pm 13.8 \mathrm{~kg}, \quad \mathrm{BCS}$ $3.4 \pm 0.5$ ) or $400 \mathrm{mg}$ progesterone (OB 400, $\mathrm{n}=8$; $56.6 \pm 13.5 \mathrm{~kg}$, BCS $3.3 \pm 0.6$ ). All progesterone devices were maintained in situ for $6 \mathrm{~d}$. At $24 \mathrm{~h}$ before device removal, $37.5 \mu \mathrm{g}$ d-cloprostenol (Prolise $^{\circledR}$; ARSA S.R.L., Buenos Aires, Argentina) laterovulvar and 300IU eCG (Novormon 5000 ${ }^{\circledR}$; Coopers, São Paulo, Brazil) i.m. were administered.

Recebido em 14 de agosto de 2017

Aceito em 4 de setembro de 2018

*Autor para correspondência (corresponding author)

E-mail: jeferson.fonseca@embrapa.br 
Blood was sampled by jugular puncture into heparinized vacuolated tubes always in the morning (0600 to $0800 \mathrm{~h}$ ) previously to feeding on Days 0 (D0) (immediately before device insertion), D0+6h (6h after), daily from D1 to D6 (progesterone removal) and $24 \mathrm{~h}$ after (D7), After collection, the tubes were kept at $5 \mathrm{C}$ until centrifugation at $1,500 \times g$ for $15 \mathrm{~min}$. The plasma was then aspired and stored at $-20 \mathrm{C}$ until analyzed for progesterone $(\mathrm{P} 4)$ concentrations. The time spent from blood collection to plasma aspiration time did not exceed two hours. Plasma P4 concentration ( $\mathrm{ng} / \mathrm{mL})$ was determined through the use of the solid phase radioimmunoassay (RIA), using a commercial kit (Beckman Coulter; Immunotech, Marseille, France) at the Hormonal Dosage Laboratory, Animal Reproduction Unit, Fluminense Federal University. The assay sensitivity and intra-assay coefficients of variation were $0.05 \mathrm{ng} / \mathrm{mL}$ and $12 \%$. In addition, all data were within the maximum and minimum points of the curve.

After device removal, estrus was monitored with the use of fertile rams twice a day $(0700$ and $1900 \mathrm{~h}$ ) and females were considered to be in estrus when allowed to be mounted. Ewes displaying signs of estrus were mated by fertile Santa Inês rams $(n=4)$ at the onset of estrus and every $12 \mathrm{~h}$ if they were still in estrus. Rams were used for approximately equal numbers of ewes from each treatment, with a ram:ewe ratio about $\leq 1: 6$. Approximately 30 days after mating, conception rate was diagnosed by a B-mode transrectal ultrasonographic scanner (KX2000G $\mathrm{Vet}^{\circledR}$, Kaixin, Xuzhou, China) with multifrequential $(4.5$ to $7.5 \mathrm{MHz})$ transducer adapted with a plastic rigid tube for use in small ruminants.

The variables determined were: estrous response (number of females in estrus/number of females induced $\times 100$ ), interval to estrus (h) (interval from device removal to first time ewe stood to be mounted), duration of estrus (interval from the first to last acceptance of mounting), conception rate (number of pregnant females/number of females exposed $\times 100)$, plasma progesterone concentration $(\mathrm{P} 4 ; \mathrm{ng} / \mathrm{mL})$. Statistical analysis was performed using all tests with $\mathrm{P}<0.05$ considered significant. Parametric variables were submitted to one way analysis of variance (ANOVA) and compared by Tukey test by the SAEG program (System for Statistical Analysis). Non-parametric variables were analyzed by the use of the chi-square test. The results are described as mean \pm SEM.

Reproductive end points are listed in Table 1. Estrus response rate was overall $87.5 \%$ (21/24).

Table 1. Reproductive parameters of Santa Inês ewes after induction of synchronous estrus with 6 days progesterone treatments ${ }^{*}$ plus cloprostenol and eCG administration $24 \mathrm{~h}$ before device removal (mean \pm SEM or \%)

\begin{tabular}{lccc} 
& \multicolumn{3}{c}{ Treatment } \\
\cline { 2 - 4 } Parameter & Control & OB 200 & OB 400 \\
\hline Estrous response (\%) & $100.0(8 / 8)$ & $62.5(5 / 8)$ & $100.0(8 / 8)$ \\
Interval to estrus (h) & $46.3 \pm 3.9^{\mathrm{a}}$ & $26.4 \pm 4.5^{\mathrm{b}}$ & $31.2 \pm 5.8^{\mathrm{a}, \mathrm{b}}$ \\
Duration of estrus (h) & $39.0 \pm 3.8$ & $36.0 \pm 7.6$ & $44.4 \pm 5.7$ \\
Conception rate (\%) & $50.0(4 / 8)$ & $50.0(4 / 8)$ & $50.0(4 / 8)$ \\
\hline
\end{tabular}

${ }^{a, b}$ Means with different superscripts within rows differed (Tukey test; $\mathrm{P}<0.05$ ). ( )Number of animals. *Treatments: CONTROL (CIDR330mg), OB 200 and OB 400 (o.b. tampon embedded with 200 or 400mg progesterone).

In sheep, it is well-known that plasma progesterone concentration (P4) increases from basal levels after ovulation, reaches the plateau during diestrus and becomes progressive lower reaching levels inferior to $1 \mathrm{ng} / \mathrm{mL}$ during proestrus (Quirke et al., 1979). At this time, this lower level of P4 $(<1 \mathrm{ng} / \mathrm{mL})$, also called as subluteal level (Minton et al., 1991; Channa et al., 2017) implies in decreasing the negative feedback of progesterone on LH pulse frequency. As a consequence, final follicular development was possible culmination in estrus behaviour and ovulation (Ginther et al., 2006). In the present study it was observed P4 under $1 \mathrm{ng} / \mathrm{mL}$ (Figure 1).

A total of fourteen ewes (14/24) had supraluteal P4 (>1ng/mL) on Day 0. P4 superior to $1 \mathrm{ng} / \mathrm{mL}$ at the moment of device removal were detected in all females in Control group, and in five ewes in OB 400 group. All the ewes in OB 200 group, had subluteal P4 $(<1 \mathrm{ng} / \mathrm{mL})$ at the moment of 
device removal. $\mathrm{P} 4$ was similar $(\mathrm{P}>0.05)$ in all treatments throughout the experimental period, except at the day of device removal, when Control had greater $(\mathrm{P}<0.05) \mathrm{P} 4(2.5 \pm 0.3 \mathrm{ng} / \mathrm{mL})$ than OB $200(0.6 \pm 0.1 \mathrm{ng} / \mathrm{mL})$ and OB 400
$(1.2 \pm 0.4 \mathrm{ng} / \mathrm{mL})$. On the following day (Day 7) P4 decreased to subluteal concentrations in all ewes of the OB 200 group, and in seven ewes of the Control and OB 400 group of treatments.
5

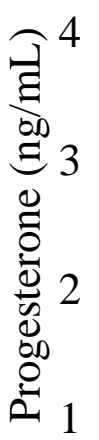

0

$\begin{array}{lll}\text { CONTROL } & \text { OB } 200 \quad \text { OB } 400\end{array}$

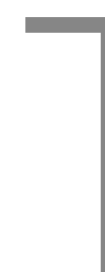

$$
\begin{array}{ccccccccc}
0 & 0+6 h & 1 & 2 & 3 & 4 & 5 & 6 & 7 \\
\multicolumn{4}{c}{\text { Period from devise insertion to removal (Day } 6)}
\end{array}
$$

Figure 1. Plasma progesterone concentration in Santa Inês ewes after receiving intravaginal commercial progesterone device (CIDR 330mg progesterone; Control) or human intravaginal tampon embedded with either 200mg (OB 200) or 400mg (OB 400) human progesterone for six days (D0-D6). ( - ) denotes the limit between subluteal and luteal levels of progesterone.

According to Figure 1, OB 200 ewes showed in average $\mathrm{P} 4$ near to limit considered as luteal until Day 4 after device insertion. Interestingly, on Day 5 (24h prior to device removal), all OB 200 ewes showed P4 inferior to $1 \mathrm{ng} / \mathrm{mL}$. It could mean that this level of P4 was not capable to inhibit LH efficiently. Thus, possibly this was the reason for shorter interval to estrus in this group. In addition, three ewes from OB 400 group showed $\mathrm{P} 4$ inferior to $1 \mathrm{ng} / \mathrm{mL}$ at device removal. This fact might be involved in intermediary interval to estrus observed in this group.

In the present study, we compared the outcomes of using a human intravaginal tampon embedded with either 200 or $400 \mathrm{mg}$ progesterone with the CONTROL group, a commercial progesterone device commonly used for estrus synchronization in sheep. All protocols studied had a satisfactory estrus response and conception rate after the treatments. Although the rates of estrus response and conception were statistically similar, the animals in the OB 200 group had a lower (numerically) response compared to the other two groups. Ewes from OB 400 group showed interval to estrus (31h) similar to CONTROL and also to those previously observed in the breed using estrous induction protocols using 60mg MAP sponges for six days 32h (Cavalcanti et al., 2012).

In conclusion, results of the present study suggest that different intravaginal devices and with different dose of progesterone can be successfully applied for estrus induction in Santa Inês ewes, without adversely affecting reproductive efficiency.

Keywords: progestagen; transition period; estrus induction; conception rate 


\section{RESUMO}

Este estudo avaliou a eficiência de três protocolos de indução de estro síncronizado em ovelhas da raça Santa Inês. Vinte e quatro ovelhas adultas foram equitativamente distribuídas em três grupos, de acordo com ordem de parto, peso corporal $(\mathrm{kg})$ e escore da condição corporal. As ovelhas receberam implante vaginal de progesterona natural por seis dias mais 37,5 $\mathrm{g}$ de d-cloprostenol laterovulvar e $300 U \mathrm{U}$ de eCG i.m., 24 horas antes da remoção do dispositivo. Ovelhas controle receberam CIDR330mg de progesterona, e as demais receberam dispositivo absorvente intravaginal humano, tamanho mini, embebido com 200 (OB200) ou 400mg (OB400) de progesterona. Coletas de sangue foram feitas nos momentos DO (antes da inserção dos dispositivos), DO+6h e diariamente, até um dia após retirada do dispositivo (D7). A progesterona $(\mathrm{ng} / \mathrm{mL})$ foi semelhante $(P>0,05)$ em todos os tratamentos ao longo do período experimental, exceto no dia da remoção do dispositivo, quando as ovelhas controle $(2,5 \pm 0,3)$ tiveram progesterona superior $(P<0,05)$ às ovelhas $O B 200(0,6 \pm 0,1)$ e $O B 400(1,2 \pm 0,4)$. O percentual de animais em estro $\left(100,0,62,5\right.$ e 100,0\%) foi semelhante $(P>0,05)$ e o intervalo para o estro $\left(46,3 \pm 3,9^{a}\right.$, $26,4 \pm 4,5^{b}$ e $\left.31,2 \pm 5,8^{a, b}\right)$ foi diferente $(P<0,05)$ entre os animais dos grupos controle, OB200 e OB400, respectivamente. A taxa de concepção das ovelhas foi de 50,0\% (4/8) para cada grupo $(P>0,05)$. Dispositivos humanos e fonte de progesterona podem ser usados para induzir o estro sincronizado em ovelhas Santa Inês.

Palavras-chave: progestágeno, período de transição, indução de estro, taxa de concepção

\section{ACKNOWLEDGMENTS}

The authors thank to Empresa Brasileira de Pesquisa Agropecuária (EMBRAPA; Project 02.13.06.026.00.04), and Fundação de Amparo à Pesquisa de Minas Gerais (FAPEMIG, Project CVZ-PPM 00201/17) for the financial support to this study. FZB is CNPq fellow and JMGSJ of CAPES.

\section{REFERENCES}

AMARANTE, A.F.T.; BRICARELLO, P.A.; ROCHA, R.A. et al. Resistance of Santa Ines, Suffolk and Ile de France sheep to naturally acquired gastrointestinal nematode infections. Vet. Parasitol., v.120, p.91-106, 2004.

BALARO, M.F.A.; SOUZA, J.M.G.; CORTÊS, L.R. et al. Sincronização e indução do estro em caprinos leiteiros. Rev. Bras. Reprod. Anim., v.41, p.330-339, 2017.

CAVALCANTI, A.S.; BRANDÃO, F.Z.; GARCIA, L.A. et al. Effects of GnRH administration on ovulation and fertility in ewes subjected to estrous synchronization. Rev. Bras. Zootec., v.41, p.1412-1418, 2012.
CHANNA, A.; MARTINS, J.P.N.; FERMINJIMENEZ-KRASSEL, J. et al. Inducing sub-luteal circulating concentrations of progesterone and persistent follicles in Holstein heifers and non-lactating cows using a modified CIDR device. Livest. Sci., v.198, p.191-194, 2017.

GINTHER, O.J.; WILTBANK, M.C.; FRICKE, P.M. et al. Selection of the dominant follicle in cattle. Biol. Reprod., v.55, p.1187-1194, 1996.

MINTON, E.; COPPINGER, T.R.; SPAETH, C.W. et al. Poor reproductive response of anestrous Suffolk ewes to ram exposure is not due to failure to secrete luteinizing hormone acutely. J. Anim. Sci., v.69, p.3314-3320, 1991.

QUIRKE, J.F.; HANRAHAN, J.P.; GOSLING, J.P. Plasma progesterone levels throughout the oestrous cycle and release of LH at oestrus in sheep with different ovulation rates. J. Reprod. Fertil., v.55, p.37-44, 1979.

SOUSA, W.H.; LÔBO, R.N.B.; MORAIS, O.R. Ovinos Santa Inês: estado de arte e perspectivas. In: SIMPÓSIO INTERNACIONAL SOBRE CAPRINOS E OVINOS DE CORTE, 2.; SIMPÓSIO INTERNACIONAL SOBRE AGRONEGÓCIO DA CAPRINOCULTURA LEITEIRA, 1., 2003, João Pessoa. Anais... João Pessoa: EMEPA-PB, 2003. p.501-522. 